\title{
Milk contamination by organophosphorus and carbamate residues present in water and animal feedstuff
}

\section{Contaminação do leite por resíduos de organofosforados e carbamatos presentes na água e alimentação animal}

\author{
Livia Cavaletti Corrêa da Silva ${ }^{1 *}$; Vanerli Beloti²; \\ Ronaldo Tamanini ${ }^{3}$; Daisy Pontes Netto ${ }^{4}$
}

\begin{abstract}
Resumo
No Brasil, as exigências legais quanto ao controle de qualidade do leite cru se restringem à análise microbiológica, físico-química e à pesquisa de antimicrobianos. Contudo, os agrotóxicos podem ser detectados no leite após a exposição dos animais em lactação a esses agentes. O objetivo deste trabalho foi pesquisar a presença de organofosforados (OF) e carbamatos (CB) em amostras de água e de alimentos fornecidos às vacas leiteiras e também no leite produzido por esses animais. Todas as amostras foram analisadas por cromatografia gasosa com um detector de nitrogênio e fósforo (CGNPD). Das 30 amostras de leite cru analisadas, os resíduos de OF foram detectados em 5 (16,67\%), todos abaixo dos limites máximos de resíduos (LMR) determinados pela legislação e não foram detectados resíduos de $\mathrm{CB}$ no leite. Os agrotóxicos pesquisados não foram detectados nas amostras de água. Do total de 98 amostras de alimentação animal, foi detectado OF em 28 amostras (28,57\%), CB em 18 $(18,37 \%)$ e ambos em 1 amostra (1,02\%). Em 3 propriedades se constatou a contaminação do leite pelos mesmos princípios ativos de OF detectados na alimentação animal. A grande ocorrência de resíduos de agrotóxicos na alimentação animal alerta para ausência de controle na sua produção, podendo essa ser uma importante fonte de contaminação do leite por esses compostos.
\end{abstract}

Palavras-chave: Leite cru, resíduos de agrotóxicos, rebanho leiteiro, contaminação

\begin{abstract}
In Brazil, the legal requirements regarding the quality control of raw milk are restricted to microbiological, physico-chemical and antimicrobial research. However, pesticides can be detected in milk after exposure of dairy cows to these agents. The present study aimed to search for the presence of organophosphorus (OPP) and carbamate (CB) pesticides in samples of water and feedstuff supplied to dairy cattle and also in the milk produced by these animals. All samples were analyzed by gas chromatography with nitrogen phosphorus detector (GC-NPD). Residues of OPP were detected in 5 (16.67\%) out of 30 raw milk samples, all bellow maximum residues limits (MRL). CB residues were not detected in milk. Pesticide residues included in the research were not detected in water samples. Within the 98 samples of the diet's components of the animals analyzed, OPP were detected in $28(28.57 \%)$ samples, CB in 18 $(18.37 \%)$, while both pesticides were detected in 1 sample (1.02\%). In 3 dairy farms it could be noted milk contamination by the same active ingredient of OPP that were detected in animal feed. High levels of animal feed contamination detected in this study raise concerns to the absent control in animal feed production and may represent an important source of milk contamination by these compounds.
\end{abstract}

Key words: Raw milk, pesticides residues, dairy herd, contamination

\footnotetext{
${ }^{1}$ Prof $^{\mathrm{a}} \mathrm{Dr}^{\mathrm{a}}$, Dept ${ }^{\mathrm{o}}$ de Medicina Veterinária Preventiva, Universidade Federal do Rio Grande do Sul, UFRGS, Porto Alegre, RS, Brasil. E-mail: liviacavaletti@gmail.com

2 Prof $^{\mathrm{a}}$ Dr $^{\mathrm{a}}$, Dept ${ }^{\mathrm{o}}$ de Medicina Veterinária Preventiva, Universidade Estadual de Londrina, UEL, Londrina, PR, Brasil. E-mail: vbeloti@uel.br

${ }_{3}$ Pesquisador Dr., Dept ${ }^{\circ}$ de Medicina Veterinária Preventiva, UEL, Londrina, PR, Brasil. E-mail: ronaldo.tamanini@gmail.com

${ }^{4} \operatorname{Prof}^{\mathrm{a}} \mathrm{Dr}^{\mathrm{a}}, \mathrm{Dept}^{\mathrm{o}}$ de Medicina Veterinária Preventiva, UEL, Londrina, PR, Brasil. E-mail: rnetto@uel.br

* Author for correspondence
} 


\section{Introduction}

Though necessary, the pesticide application brings undesirable consequences such as the remaining of residues in agriculture products and the environment. Pesticide residues are found contaminating water (GARCÍA DE LLASERA; BERNAL-GONZÁLEZ, 2001; PARREIRA et al., 2001; SANTOS NETO; SIQUEIRA, 2005; VEIGA et al., 2006) and animal feedstuff (FDA, 2003; KAN; MEIJER, 2007; TSIPLAKOU et al., 2010). Consequently, after ingested by the lactating animals, pesticide residues present in water and animal feedstuff can be detected in milk.

Studies on pesticide residues in milk and dairy products are constantly focused on searching for organochlorine pesticides (HECK et al., 2007; KUMAR et al., 2005; NAG; RAIKWAR, 2008), due to its high persistence in the environment and its toxicity. However, the prohibition of its usage in 1985, in Brazil, created the need of searching for its most common replacers, organophosphorus (OPP) and carbamate $(\mathrm{CB})$ pesticides.

Data reported by "PAMVet" Program for Analysis of Residues of Veterinary Drugs in Foods of Animal Origin show violations related with improper use of pesticides in lactating cows (ANVISA, 2009). Despite monitoring programs such PAMVet and the National Program for Residues Control (BRASIL, 1999), daily quality control of milk, as determined by current legislation, is limited to microbiological and physicochemical evaluation of the product and research of antibiotics (BRASIL, 2011). As a result, consumers can be exposed to these substances.

Milk contamination with OPP and CB pesticides poses as consumer's risk, since these substances have been associated with adverse human health effects such as cancer, reproduction toxicity and neurotoxicity by routes that include ingestion of pesticide residues through diet (BOOBIS et al., 2008; PEIRIS-JOHN; WICKREMASINGHE, 2008).
Due to the risk presented to public health by milk contamination with OPP and CB residues, this study aimed to search for the presence of these residues in water and feedstuff supplied to dairy cattle and in milk produced by these animals.

\section{Material and Methods}

\section{Sampling}

Thirty dairy farms located in North of Parana State, in the cities of Londrina (12), Rolândia (8) and Tamarana (4) - and in São Paulo State, in Presidente Prudente (6) were studied from April to August 2007. The dairy farms were selected based on their profile, in order to represent the regional production regarding animal handling practices and installation characteristics. Samples of milk (30), water (30) and animal feedstuff (98) supplied to dairy cattle were collected simultaneously, on each farm, adding up to 158 samples.

Raw milk samples were collected directly from the cooling tanks of the farms, after homogenization, representing milk of all lactating cows. All animal feedstuff components and also the water supplied to the dairy cows were collected on each farm. The water samples were collected from wells or mines, except for two samples collected from dams and one from local water supply net. All samples were obtained by the collection of $300 \mathrm{~mL}$ or $\mathrm{g}$ in plastic bags, which were immediately placed in coolers with recyclable ice for transportation to the Laboratory of Inspection of Animal Origin Products at Londrina State University. In the laboratory, samples were homogenized and then divided into two aliquots that remain stored at $-18^{\circ} \mathrm{C}$ up to analyzed.

In order to eliminate the possibility of milk contamination by the direct use of veterinary drugs on lactating cows, in all studied farms a questionnaire was applied at the moment of sample collection. Questions included information concerning the usage of veterinary drugs on the lactation cows, dosage and withdraw periods adopted. 


\section{Analytic methodology}

For water samples two liquid-liquid extractions were carried out with dichloromethane and $\mathrm{NaCl}$ $20 \%$ solution, followed by filtration with qualitative filter containing anhydrous sodium sulfate. For milk and feed samples $5 \mathrm{~g} / \mathrm{mL}$ of the sample were placed in an erlenmeyer and added with $2 \mathrm{~mL}$ of Formic acid and $30 \mathrm{~mL}$ of $\mathrm{n}$-hexane (HPLC purity). The mixture was then agitated on orbital shaker table for 30 minutes and filtered in qualitative filter containing anhydrous sodium sulfate. Cleanup of the extracts obtained was performed in glass column containing $5 \mathrm{~g}$ of Florisil previously moistened with $\mathrm{n}$-hexane.

For detection and quantification of organophosphorus and carbamate pesticides all samples were analyzed by Gas chromatography with a nitrogen phosphorus detector (GC-NPD), Varian 3600 with Auto sampler 8200. A capillary column DB-5 (30 m x $250 \mathrm{~mm}$ x 0,25 $\mu \mathrm{m})$ was used. The carrier gas used was nitrogen at a flow rate of $1 \mathrm{~mL} \cdot \mathrm{min}^{-1}$. Injection was proceeded in the splitless mode at $250^{\circ} \mathrm{C}$ and detector temperature was $300^{\circ} \mathrm{C}$. Detection limit was $0.01 \mathrm{ng} . \mathrm{mL}^{-1}$ while quantification limit was $0.1 \mathrm{ng} \cdot \mathrm{mL}^{-1}$ (AOAC, 2003; DELGADO et al., 2001; NUNES; CAMÕES; FOURNIER, 1997).

The standards used to organophosphorus were: Chlorpyriphos, Coumaphos, Diazinon, Dichlorvos,
Dimethoate, Disulphoton, Ethion, Fenthion, Phorate, Phosalone, Malathion, Methamidophos, Mevinphos, Meta-systos, Methyl-parathion, Monocrotophos and Triclorphon (Sigma Inc.USA). Aldicarb, Bendiocarb, Carbaryl, Carbofuran, Carbosulfan, Methomyl, Propoxur and Thiodicarb. (Sigma Inc.-USA) were used as standards to carbamates. All gas chromatography analyses were carried out in the Center of Toxicology Assistance (CEATOX), in the Institute of Bioscience of the Paulista State University (UNESP), Botucatu - São Paulo.

Descriptive statistics were calculated for each active principle and for each type of feedstuff separately, using Microsoft Excel ${ }^{\circledR}$ software (2007).

\section{Results and Discussion}

\section{Milk}

Organophosphorus (OPP) residues were detected in $5(16.67 \%)$ samples of milk (Table 1$)$, from Londrina-PR, while carbamates $(\mathrm{CB})$ residues were not detected in any of the milk samples evaluated. Brazilian legislation does not determine Maximum Residues Limit (MRL) to these particular OPP residues found in milk (BRASIL, 2013), however, residues were bellow MRL established by Codex Alimentarius (2010) and EEC (2005).

Table 1. Residues of organophosphorus detected in 5 of 30 milk samples collected at dairy farms on North of Parana State from April to august 2007 by gas chromatography (GC-NPD) and Maximum residues limits established by Codex Alimentarius (2010).

\begin{tabular}{cccc}
\hline Sample & $\begin{array}{c}\text { Active } \\
\text { Ingridient }\end{array}$ & $\begin{array}{c}\text { Quantification } \\
\text { ng.mL }\end{array}$ & $\begin{array}{c}\text { MRL } \\
\text { ng.mL }\end{array}$ \\
\hline $\mathrm{a}$ & Fenthion & 2.77 & 50 \\
\hline \multirow{2}{*}{$\mathrm{b}$} & Fenthion & 1.02 & 50 \\
& Dimethoate & 0.14 & 50 \\
\hline \multirow{2}{*}{$\mathrm{c}$} & Dimethoate & 0.15 & 50 \\
& Malathion & 0.61 & $10^{*}$ \\
\hline \multirow{2}{*}{$\mathrm{d}$} & Fenthion & 0.54 & 50 \\
& Coumaphos & 0.53 & 500 \\
\hline $\mathrm{e}$ & Malathion & 1.46 & $10^{*}$ \\
\hline
\end{tabular}

*MRL established by EEC, 2005.

Source: Elaboration of the authors. 
Studies demonstrate that pesticides residues detected in milk are, in general, below MRL and its presence alone does not translate into health risk to the consumers (BERTRAND, 2010). However, some authors have questioned the risk of prolonged low-level exposure to these compounds (BOOBIS et al., 2008; PEIRIS-JOHN; WICKREMASINGHE, 2008).

Given that direct use of pesticides to parasite control in lactating cows can be a source of milk contamination, when the withdrawal period is not respected, the use of these substances was investigated by a questionnaire in this study. The use of OPP as acaricide was observed in 11 (36.7\%) of 30 dairy farms studied. However, from the 5 farms that presented OPP residues in milk only two used OPP as an acaricide and in those farms the active ingredient used in the cows was different from those detected in milk samples by GC-NPD. Therefore the use of pesticide in lactating cows in this study could not be related with milk contamination.

Although not recommended for lactating cows, the use of avermectins was observed in 8 (26.7\%) of the studied farms. This data is in accordance with the elevated number of violations reported by a monitoring assessment that detected ivermectin in $41.29 \%$ from 475 samples of UHT milk and in $52.17 \%$ from 140 milk powder samples, all bellow MRL (ANVISA, 2009). Other substances used to control ectoparasites in the studied farms were inhibitors of benzoylphenylurea chitin synthesis in 5 farms (16.7\%), pyrethroids in $4(13.3 \%)$ and formamidine in 2 farms $(6.6 \%)$.

In Brazil, studies concerning OPP and $\mathrm{CB}$ milk contamination are not frequent; still some researchers report this problem. Fagnani et al. (2011) performed a similar study in Pernambuco, Brazil, and found $6(20 \%)$ out of 30 samples of raw milk contaminated with OPP, 5 (16.7\%) were contaminated with $\mathrm{CB}$, and one sample with both pesticides. Nero et al. (2007) analyzed 209 samples of raw milk in four states from Brazil (RS, PR, SP and $\mathrm{MG}$ ), using thin layer chromatography, and found an elevated number of positive samples 196 (93.8\%) for OPP and/or CB. In Pernambuco, Brazil, Mattos et al. (2010) detected OPP and/ or $\mathrm{CB}$ residues in $47 \%$ out of 53 raw milk samples.

Contamination of milk with OPP is reported throughout the world, although its frequency varies greatly among different countries. Abou Donia et al. (2010) found no OPP in buffalo nor cow milk dairy farms in Egypt, while searching for malathion, pirimiphos methyl and dimethoate residues.

Pagliuca et al. (2006) analyzed 135 raw milk samples in Italy, from which 47 (34\%) contained acephate or chlorpyriphos. In a more recent study, at the same region, an apparent decrease in contamination was perceived, $4.4 \%$ of 298 samples presented residues (GAZZOTTI et al., 2009).

Santaeufemia et al. (2006) examined 242 raw milk samples in Spain and found residues of dichlorvos, coumaphos and methyl-parathion in $19(7.97 \%)$ samples. Still in Spain, Melgar, Santaeufemia and Garcia (2010) detected OPP residues of dichlorvos (5.78\%), coumaphos (2.06 $\%$ ) and methyl-parathion (0.83\%) in 242 raw milk samples.

In the present study three milk samples presented two different OPP residues simultaneously (Table 1). That might represent an increased risk to consumer's health, once those substances have the same mode of action and their effects in the organism could be increased (BOOBIS et al., 2008). Milk contamination with pesticide residues is a matter of great concern given that milk is an important part of human nutrition, especially for children. In addition, it is used to produce several dairy products, which may retain the contamination, since industrial processing is unable to eliminate pesticide residues (KAUSHIK; SATYA; NAIK, 2009). 


\section{Water}

Despite the fact that OPP and CB presence in water is reported by different studies (GARCÍA DE LLASERA AND BERNAL-GONZÁLEZ, 2001; PARREIRA et al., 2001; SANTOS NETO; SIQUEIRA, 2005; VEIGA et al., 2006; FAGNANI et al., 2011), residues from those pesticides were not detected in water samples in the present study. This may be due to its high degradability in water (VEIGA et al., 2006).

The absence of pesticide in water was also reported by Rovedatti et al. (2001), which analyzed 60 water samples in Buenos Aires searching for OPP and OC (organochlorine) pesticides. In another study, OPP residues were only detected in six $(7.5 \%)$ out of 80 samples of well waters in Nicaragua (CASTILHO et al., 2000).

\section{Animal feedstuff}

In regard to animal feedstuff, from 98 samples collected, 47 (47.96\%) presented pesticide residues. From the 47 positive samples, 18 (18.37\%) were contaminated with $\mathrm{CB}$ residues (Table 2), 28 (28.59\%) with OPP (Table 3), and 1 (1.02\%) sample was contaminated by both pesticides. More frequent residues detected were fenthion, aldicarb, malathion and dimethoate. Contamination of animal feedstuff samples was similar in all four districts studied. Multiple pesticides (more than 1) were detected in 15 samples. Nine of those presented two residues concomitantly (wheat bran, soy bran, cotton seed, cotton bran, commercial feed and 4 samples of corn silage), 5 samples presented three residues (commercial feed, pasture, wheat bran and 2 samples of corn silage) and 1 sample of straw presented four different pesticide residues.

Considering only once the samples that presented more than one residue and contamination by OPP and/or $\mathrm{CB}$, most frequently contaminated feed components found in this study were commercial feed 8/12 (66.67\%), feedstuffs produced with soy bean and corn 14/26 (53.84\%) and corn silage $11 / 22(50.0 \%)$. Pasture was the least contaminated feedstuff, only $4(17.39 \%)$ out of 23 samples contained detectable pesticide residues.

Table 2. Carbamate residues detected in 19 samples of animal feedstuff from 30 Brazilian dairy farms, collected from April to August 2007, by gas chromatography (GC-NPD).

\begin{tabular}{|c|c|c|c|c|c|}
\hline Sample & $\begin{array}{c}\text { Detected } \\
\text { residue }\end{array}$ & $\begin{array}{l}\text { Mean } \\
\text { ng.g } \\
\end{array}$ & $\begin{array}{l}\text { Standard } \\
\text { deviation }\end{array}$ & $\begin{array}{l}\text { Positive Samples } / \\
\text { Samples analyzed }\end{array}$ & $\%$ \\
\hline Pasture & aldicarb & 0.08 & - & $1 / 23$ & 4.4 \\
\hline \multirow{2}{*}{ Corn silage } & aldicarb & 0.19 & 0.12 & $4 / 22$ & 18.2 \\
\hline & carbofuran & 0.38 & - & $1 / 22$ & 4.5 \\
\hline Commercial & carbaryl & 0.21 & - & $1 / 12$ & 8.3 \\
\hline feed & aldicarb & 0.12 & 0.01 & $2 / 12$ & 16.7 \\
\hline Corn & aldicarb & 0.08 & 0.05 & $2 / 11$ & 18.2 \\
\hline \multirow{2}{*}{ Soy (bran, hull) } & aldicarb & 0.24 & 0.12 & $2 / 11$ & 18.2 \\
\hline & carbaryl & 0.15 & - & $1 / 11$ & 9.1 \\
\hline Corn and soybean residues & carbofuran & 0.11 & - & $1 / 4$ & 25.0 \\
\hline Barley & carbofuran & 0.25 & 0.04 & $2 / 4$ & 50.0 \\
\hline Cotton seeds & aldicarb & 0.18 & - & $3 / 1$ & 33.3 \\
\hline Urea & carbofuran & 0.18 & - & $1 / 1$ & 100.0 \\
\hline Mineral salt & $\mathrm{ND}^{\mathrm{b}}$ & - & - & $0 / 4$ & - \\
\hline Wheat & ND & - & - & $0 / 2$ & - \\
\hline Straw & ND & - & - & $0 / 1$ & - \\
\hline Total & - & - & - & $19^{c} / 98$ & 19.39 \\
\hline
\end{tabular}

a) Presence of at least one active principle, b) ND - not detected; c) One sample of silage was positive for both fenthion and aldicarb and was included in the total of samples positive to CB.

Source: Elaboration of the authors. 
The high frequency of feedstuff samples contaminated with pesticide residues found in this study is remarkable. In Pernambuco, Brazil, the feed and water supplied to dairy cattle was pointed out as a possible source of milk contamination. In agreement with results found in this study, Fagnani et al. (2011) also detected the same active principles of OPP and CB contaminating milk and feedstuff samples. That study also found a high occurrence of feedstuff contamination; from 48 analyzed samples, $22(45.83 \%)$ were contaminated with OPP or CB.

Tsiplakou et al. (2010) conducted a study in Greece, with animal feedstuff supplied to dairy goats and sheep, where most of feed samples were contaminated with endosulfan, but no residues were detected in milk samples. However, in 4 samples of concentrate, malathion, pirimiphos methyl, dimethoate and carbaryl were detected, and in one sample of alfalfa hay, carbaryl was detected. In the same study, pasture samples did not present pesticides residues (TSIPLAKOU et al., 2010), result similar to the one found in the present study, where the pasture was the least contaminated feed examined.

Dalvie and London (2009) reported the detection of OPP pesticides in all 84 samples of wheat analyzed in their study. In $30 \%$ of those samples multiple pesticides were detected. The most frequent pesticides detected were malathion (99\%) and chlorpyriphos (17\%).

Table 4 shows the association between pesticide residues detected in animal feedstuff and those detected in milk. In three out of five dairy farms, animal feedstuff was apparently the source of milk contamination, since it was contaminated with the same active ingredient found in milk samples. Consequently, the great occurrence of pesticide residues detected in animal feedstuff in this study could present potential risk to milk and dairy consumers.

Table 3. Organophosphorus residues detected in 29 samples of animal feedstuff from 30 Brazilian dairy farms, collected from April to August 2007, by gas chromatography (GC-NPD).

\begin{tabular}{|c|c|c|c|c|c|}
\hline Sample & $\begin{array}{l}\text { Detected } \\
\text { Residue }\end{array}$ & $\begin{array}{l}\text { Mean } \\
\text { ng.g }\end{array}$ & $\begin{array}{l}\text { Standard } \\
\text { deviation }\end{array}$ & $\begin{array}{l}\text { Positive samples }{ }^{\mathrm{a}} \\
\text { analyzed samples }\end{array}$ & $\%$ \\
\hline \multirow{3}{*}{ Pasture } & Dichlorvos & 0.22 & - & $1 / 23$ & 4.35 \\
\hline & Fenthion & 0.78 & 0.29 & $2 / 23$ & 8.7 \\
\hline & Methyl-parathion & 3.95 & 2.50 & $2 / 23$ & 8.7 \\
\hline \multirow{5}{*}{ Corn silage } & Dichlorvos & 4.67 & 6.11 & $3 / 22$ & 13.6 \\
\hline & Dimethoate & 0.02 & - & $1 / 22$ & 4.5 \\
\hline & Fenthion & 4.16 & 6.74 & $5 / 22$ & 22.7 \\
\hline & Malathion & 1.36 & 0.61 & $5 / 22$ & 22.7 \\
\hline & Methyl-parathion & 3.70 & 1.77 & $2 / 22$ & 9.1 \\
\hline \multirow{6}{*}{$\begin{array}{l}\text { Commercial } \\
\text { feed }\end{array}$} & Diazinon & 3.15 & - & $1 / 12$ & 8.3 \\
\hline & Dichlorvos & 1.70 & - & $1 / 12$ & 8.3 \\
\hline & Dimethoate & 0.22 & 0.06 & $2 / 12$ & 16.7 \\
\hline & Fenthion & 1.33 & - & $1 / 12$ & 8.3 \\
\hline & Malation & 3.74 & - & $1 / 12$ & 8.3 \\
\hline & Methyl-parathion & 11.84 & - & $1 / 12$ & 8.3 \\
\hline \multirow{3}{*}{ Corn } & Dichlorvos & 0.78 & - & $1 / 11$ & 9.1 \\
\hline & Dimethoate & 0.93 & 0.95 & $2 / 11$ & 18.2 \\
\hline & Fenthion & 3.70 & - & $1 / 11$ & 9.1 \\
\hline \multirow{2}{*}{ Soy (bran, hull) } & Dimethoate & 0.20 & - & $1 / 11$ & 9.1 \\
\hline & Malathion & 1.79 & 0.55 & $2 / 11$ & 18.2 \\
\hline \multirow{2}{*}{ Corn and soybean residues } & Fenthion & 1.68 & - & $1 / 4$ & 8.3 \\
\hline & Malathion & 0.81 & - & $1 / 4$ & 8.3 \\
\hline
\end{tabular}


continuação

\begin{tabular}{|c|c|c|c|c|c|}
\hline Barley & Fenthion & 2.80 & - & $1 / 4$ & 25.0 \\
\hline Mineral salt & Fenthion & 3.30 & - & $1 / 4$ & 25.0 \\
\hline \multirow{2}{*}{ Cotton seeds } & Malathion & 0.35 & - & $1 / 3$ & 33.3 \\
\hline & Fenthion & 2.16 & - & $1 / 3$ & 33.3 \\
\hline \multirow{4}{*}{ Wheat bran } & Dimethoate & 0.15 & - & $1 / 2$ & 50.0 \\
\hline & Ethion & 1.54 & - & $1 / 2$ & 50.0 \\
\hline & Fenthion & 2.92 & 0.52 & $2 / 2$ & 100.0 \\
\hline & Malathion & 3.53 & - & $1 / 2$ & 50.0 \\
\hline \multirow{4}{*}{ Straw } & Dimethoate & 0.10 & - & $1 / 1$ & 100.0 \\
\hline & Fenthion & 2.60 & - & $1 / 1$ & 100.0 \\
\hline & Coumaphos & 1.53 & - & $1 / 1$ & 100.0 \\
\hline & Phosalone & 3.45 & - & $1 / 1$ & 100.0 \\
\hline Urea & $\mathrm{ND}^{\mathrm{b}}$ & - & - & $0 / 1$ & - \\
\hline Total & - & - & - & $29^{c} / 98$ & $29.59^{\circ}$ \\
\hline
\end{tabular}

a) Presence of at least one active principle, b) ND - not detected; c) One sample of silage was positive for both fenthion and aldicarb.

Source: Elaboration of the authors.

Methods to control pesticide contamination from feedstuff are known, however its implementation can be complicated and expensive (KAN; MEIJER, 2007). Brazilian legislation that determines minimum requirements to animal feedstuff does not establish MRL to pesticides (BRASIL, 1988). In addition, feedstuff supplied to production animals is often acquired from other farms, making it difficult to control the usage of pesticides on its production. Nevertheless, the high presence of pesticide residues found in animal feedstuff calls for improvement in residue control, as it can affect directly milk safety and consumer's health.

Table 4. Comparison among detected pesticides residues in animal feedstuff supplied to lactating animals and in milk produced by those animals, from 3 dairy farms located at Londrina district, Paraná State, Brazil, by gas chromatography (GC-NPD).

\begin{tabular}{cccccc}
\hline $\begin{array}{c}\text { Milk } \\
\text { sample }\end{array}$ & $\begin{array}{c}\text { Detected } \\
\text { residue }\end{array}$ & ng/mL & $\begin{array}{c}\text { Feedstuff } \\
\text { Sample }\end{array}$ & $\begin{array}{c}\text { Detected } \\
\text { Residues }\end{array}$ & ng.g $^{-1}$ \\
\hline $\mathrm{a}$ & Fenthion & 2.77 & Corn & Fenthion & 3.7 \\
\hline \multirow{2}{*}{$\mathrm{b}$} & Fention & 1.02 & $\begin{array}{c}\text { Corn and soy } \\
\text { bran }\end{array}$ & Fenthion & 1.68 \\
& Dimethoate & 0.14 & - & - & - \\
\hline \multirow{2}{*}{$\mathrm{c}$} & Dimethoate & 0.15 & Soy bran & Dimethoate & 0.2 \\
\cline { 2 - 6 } & Malathion & 0.61 & Soy bran & Malathion & 2.18 \\
\hline
\end{tabular}

The text in bold highlights the correspondence between the active ingredients found both in milk and in feedstuff samples. Source: Elaboration of the authors. 


\section{Conclusions}

Based on the data presented, organophosphorus residues are present in milk produced at dairy farms from Londrina district of Paraná State, Brazil. In contrast, carbamate residues were not detected in milk. However, the residues of OPP found in milk are all bellow maximum residues limits determined by international legislation.

Feedstuff supplied to lactating animals is contaminated with organophosphorus and carbamate residues. This study demonstrates the similarity between organophosphorus residues found in milk and in animal feedstuff samples, therefore feedstuff contamination may lead to milk contamination, and consequent risk to milk and dairy consumers. Thus, the implementation of programs to control pesticide residues in feedstuff supplied to lactating animals is important to control pesticide residues in milk and consequently to improve food safety.

\section{References}

ABOU DONIA, M. A.; ABOU-ARAB, A. A. K.; ENB, A.; EL-SENAIT, M. H.; ABD-RABOU, N. S. Chemical composition of raw milk and the accumulation of pesticide residues em milk products. Global Veterinaria, Dubai, v. 4, n. 1, p. 6-14, 2010.

AGÊNCIANACIONAL DE VIGILÂNCIA SANITÁRIA - ANVISA. Resolução RDC n. 253 de 16 de setembro de 2003. Cria o programa de análises de resíduos de medicamentos veterinários em alimentos de origem animal - PAMVet. Diário Oficial [da] União, Brasília, 18 set. 2003. Seção 1, n. 181, p. 90-91.

PAMvet - Monitoramento de resíduos em leite exposto ao consumo ( $5^{\circ}$ e $6^{\circ}$ anos de atividades). relatório 2006-2007. 2009. Disponíel em: <http://www.anvisa. gov.br>. Acesso em: 3 jun. 2012.

ASSOCIATION OF OFFICIAL ANALYTICAL CHEMISTS - AOAC. Official methods of analysis of AOAC international. 17. ed. Gaithersburg: AOAC International, 2003. $141 \mathrm{p}$.

BERTRAND, S. Pesticide consumption at farm level and residues in the environment and in milk. Bulletin of the International Dairy Federation Special Issue, Brussels, n. 443 , p. 33-38, 2010.
BOOBIS, A. R.; OSSENDORP, B. C.; BANASIAK, U.; HAMEY, P. Y.; ISTVAN SEBESTYENE, I.; MORETTO, A. Cumulative risk assessment of pesticide residues in food. Toxicology Letters, Amsterdam, v. 180, n. 2, p. 137 150, 2008.

BRASIL. Ministério da Agricultura. Portaria ${ }^{\circ} .07$ de 09 de novembro de 1988. Aprova os padrões mínimos de matéria-prima destinada à alimentação animal. Diário Oficial [da] República Federativa do Brasil, Brasília, DF, 11 nov.1988, Seção 1, p. 21968.

Ministério da Agricultura, Pecuária e Abastecimento. Instrução Normativa $\mathrm{N}^{\circ} 42$. Altera o plano nacional de controle de resíduos em produtos de origem animal - PNCR e os Programas de controle de resíduos em carne - PCRC, Mel - PCRM, leite PCRL e Pescado - PCRP. Diário Oficial [da] República Federativa do Brasil, Brasília, DF, 22 dez. 1999. Seção 1, p. 213.

. Instrução Normativa $n^{\circ} 17$ de 29 de maio de 2013. Aprova os programas de controle de resíduos e contaminantes em carnes leite, mel, ovos e pescado do exercício de 2013. Diário Oficial [da] República Federativa do Brasil, Brasília, DF, 31 maio 2013, Seção 1, n. 103, p. 6-12.

. Instrução Normativa ${ }^{0} 62$, de 29 de dezembro de 2011. Aprova o regulamento técnico de produção, identidade e qualidade do leite tipo a, o regulamento técnico de identidade e qualidade de leite cru refrigerado, o regulamento técnico de identidade e qualidade de leite pasteurizado e o regulamento técnico da coleta de leite cru refrigerado e seu transporte a granel. Diário Oficial [da] República Federativa do Brasil, Brasília, 30 dez. 2011. Seção 1, n. 251, p. 6.

CASTILHO, J. A. A.; FENZL, N.; GUILLENC, S. M.; NASCIMENTO, F. S. Organochlorine and organophosphorus pesticide residues in the Atoya river basin, Chinandega, Nicaragua. Environmental Pollution, Barking, v. 110, n. 3, p. 523-533, 2000.

CODEX ALIMENTARIUS - FAO/WHO Food standards. Codex pesticides residues in food and feed online database, 2010. Available at :<http://www. codexalimentarius.net $>$. Access at: 15 jul. 2013.

DALVIE, M. A.; LONDON, L. Risk assessment of pesticide residues in South African raw wheat. Crop Protection, Guildford, v. 10, n. 28, p. 864-869, 2009.

DELGADO, M. J. S.; BARROSO, S. R.; FERNANDEZTOSTADO, G. T.; POLO-DiEZ, L. M. Stability studies of carbamate pesticides and analysis by gas chromatography with flame ionization and nitrogen-phosphorus detection. Journal of Chromatography A, Amsterdam, v. 921, n. 2, p. 287-296, 2001. 
EUROPEAN ECONOMIC COMMUNITY - EEC. Council directive 91/414/EEC, 2005. On maximum residue levels of pesticides in or on food and feed of plant and animal origin and amending. Available at: <http:// www.eur-lex.europa.eu>. Access at: 17 jul. 2013.

FAGNANI, R.; BELOTI, B.; BATTAGLINI, A. P. P.; TAMANINI, R.; DUNGA, K. D. S. Organophosphorus and carbamates residues in milk and feedstuff supplied to dairy cattle. Pesquisa Veterinária Brasileira, Rio de Janeiro, v. 7, n. 31, p. 598-602, 2011.

FOOD AND DRUG ADMINISTRATION - FDA. Pesticide program - residue monitoring, 2003. Available at: <http://www.cfsan.fda.gov/ acrobat/pes03rep.pdf $>$. Access at: 15 jan. 2013.

GARCÍA DE LLASERA, M. P.; BERNAL-GONZÁLEZ, M. Presence of carbamate pesticides in environmental waters from the northwest of Mexico: determination by liquid chromatography. Water Research, New York, v. 35, n. 8, p. 1933-1940, 2001.

GAZZOTTI, T.; STICCA, P.; ZIRONI, E.; LUGOBONI, B.; SERRAINO, A.; PAGLIUCA, G. Determination of 15 organophosphorus pesticides in Italian raw milk. Bulletin of Environment Contamination and Toxicology, New York, v. 82, n. 2, p. 251-254, 2009.

HECK, M. C.; SANTOS, J. S.; BOGUSZ JUNIOR, S.; COSTABEBER, I.; EMANUELLI, T. Estimation of children exposure to organochlorine compounds through milk in Rio Grande do Sul, Brazil. Food Chemistry, London, v. 102, n. 1, p. 288-294, 2007.

KAN, C. A.; MEIJER, G. A. L. The risk of contamination of food with toxic substances present in animal feed. Animal Feed Science and Technology, Amsterdam, v. 133, n. 1-2, p. 84-108, 2007.

KAUSHIK, G.; SATYA, S.; NAIK, S. N. Food processing a tool to pesticide residue dissipation - a review. Food Research International, Barking, v. 42, n. 1, p. 26-40, 2009.

KUMAR, A.; DAYAL, P.; SINGH, G.; PRASAD, F. M.; JOSEPH, P. E. Persistent Organochlorine Pesticide Residues in Milk and Butter in Agra City, India: A Case Study. Bulletin of Environment Contamination and Toxicology, New York, v. 75, n. 1, p. 175-179, 2005.

MATTOS, M. R.; BELOTI, V.; TAMANINI, R.; MAGNANI, D. F.; NERO, L. A.; BARROS, M. A. F.; PIRES, E. M. F.; PAQUEREAU, B. P. D. Qualidade do leite cru produzido na região do agreste de Pernambuco, Brasil. Semina: Ciências Agrárias, Londrina, v. 31, n. 1, p. 173-182, 2010.
MELGAR, M. J.; SANTAEUFEMIA, M.; GARCIA, M. A. Organophosphorus pesticide residues in raw milk and infant formulas from Spanish northwest. Journal of Environmental Science and Health Part B, New York, v. 45, n. 7, p. 595-600, 2010.

MICROSOFT Office. Version 2007. [S.1.]: Microsoft Corporation, 2007. CD-ROM.

NAG, S. K.; RAIKWAR, M. K. Organochlorine pesticide residues in bovine milk. Bulletin of Environment Contamination and Toxicology, New York, v. 80, n. 1, p. 5-9, 2008.

NERO, L. A.; MATTOS, M. R.; BELOTI, V.; BARROS, M. A. F.; NETTOS, D. P.; FRANCO, B. D. G. M. Organofosforados e carbamatos no leite produzido em quatro regiões leiteiras no Brasil: ocorrência e ação sobre Listeria monocytogenes e Salmonella spp. Ciência e Tecnologia de Alimentos, Campinas, v. 27, n. 1, p. 201204, 2007.

NUNES, M. J.; CAMÕES, M. F.; FOURNIER, J. Analysis of organophosphorus, organochlorine and pyrethroide inseticides in medicinal plants. Chromatographia, New York, v. 44, n. 1, p. 505-5139-10, 1997.

PAGLIUCA, G.; SERRAINO, A.; GAZZOTTI, T.; ZIRONI, E.; BORSARI, A.; ROSMINI, R. Organophosphorus pesticides residues in Italian raw milk. Journal of Dairy Research, Cambridge, v. 73, n. 3, p. 340-344, 2006.

PARREIRA, F. V.; PANIAGO, E. B.; CARVALHO, C. R.; AFONSO, R. J. C. F. Avaliação da presença de pesticidas n-metilcarbamatos e seus produtos de degradação nas águas da região de Pará de Minas (MG) Brasil. Revista de Ecotoxicologia e Meio Ambiente, Curitiba, v. 11, p. 77-92, 2001.

PEIRIS-JOHN, R. J.; WICKREMASINGHE, R. Impact of low-level exposure to organophosphates on human reproduction and survival. Transactions of the Royal Society of Tropical Medicine and Hygiene, London, v. 102, n. 3, p. 239-245, 2008.

ROVEDATTI, M. G.; CASTAÑÉ, P. M.; TOPALIÁN, M. L.; SALIBIÁN, A. Monitoring of organochlorine and organophosphorus pesticides in the water of the Reconquista River (Buenos Aires, Argentina). Water Research, New York, v. 35, n. 14, p. 3457-3461, 2001.

SANTAEUFEMIA, M.; MELGAR, M. J.; CEPEDA, A.; GARCÍA, M. A. Estudio de la contaminación por plaguicidas organofosforados y triazinas em leche procedente de diversas rutas de recogida. Revista de Toxicología, Madrid, v. 23, n. 1, p. 7-10, 2006. 
SANTOS NETO, A. J.; SIQUEIRA, M. E. P. B. TSIPLAKOU, E.; ANAGNOSTOPOUlOS, C. J.; Análise de praguicidas organofosforados em água por LIAPIS, K.; HAROUTOUNIAN, S. A.; ZERVAS, G. extração em fase sólida (SPE) utilizando discos C18 e cromatografia em fase gasosa: avaliação da contaminação do reservatório de Furnas (MG-Brasil). Química Nova, São Paulo, v. 28, n. 5, p. 747-750, 2005.

Pesticides residues in milks and feedstuff of farm animals drawn from Greece. Chemosphere, Oxford, v. 80, n. 5, p. 504-512, 2010.

VEIGA, M. M.; SILVA, D. M.; VEIGA, L. B. E.; FARIA, M. V. C. Análise da contaminação dos sistemas hídricos por agrotóxicos numa pequena comunidade rural do Sudeste do Brasil. Cadernos de Saúde Pública, Rio de Janeiro, v. 22, n. 11, p. 2391-2399, 2006. 